\title{
Comparison between Holistic Museum Visitors and
}

\section{Utilitarian Museum Visitors}

\author{
Taşkın Dirsehan (Corresponding author) \\ Faculty of Economic and Administrative Sciences, Department of Business Administration \\ Marmara University, Anadoluhisarı Campus, Beykoz / İstanbul, 34820, Turkey \\ Tel: 90-216-308-2226 E-mail: taskin.dirsehan@marmara.edu.tr
}

Azize Müge Yalçın

Faculty of Economic and Administrative Sciences, Department of Business Administration

Marmara University, Anadoluhisarı Campus, Beykoz / İstanbul, 34820, Turkey

Tel: 90-216-308-2226 E-mail:myalcin@marmara.edu.tr

$\begin{array}{lc}\text { Received: July 19, } 2011 \quad \text { Accepted: August 22, } 2011 \quad \text { Published: November 1, } 2011 \\ \text { doi:10.5539/ijms.v3n4p78 } & \text { URL: http://dx.doi.org/10.5539/ijms.v3n4p78 }\end{array}$

This article is derived from Taşkın Dirsehan's unpublished master thesis accepted from Marmara University Institute of Social Sciences in June 2011.

\begin{abstract}
In marketing strategies, the consumer-focus approach reveals customer experience management as a differentiating tool for competitive advantage in increasing competitive environment. In recent years, museums compete with other leisure and educational institutions such as other museums, theatres, cinemas and amusement parks. Thus, customer experience management provides a competitive advantage for museums.

In this study, museum visitors are clustered according to their experiential appeals and the differences for their post experience dimensions (learning in museum, visitor satisfaction, visit intensification, revisit intention and word-of-mouth communication) are analyzed. In conclusion, as a support for customer experiences' competitive advantage, it's revealed that the results of these dimensions are significantly higher for holistic museum visitors than those for utilitarian museum visitors.
\end{abstract}

Keywords: Customer experience management, Experiential marketing, Museum marketing, Structural equation model

\section{Introduction}

The evolution of marketing in the history is based on the increasing competition from an era where every product has its waiting consumers to an era where the supply exceeds much more the demand. The strategies of organizations change also in each era to succeed in dynamic markets (Keith, 1960; Kotler et all., 1999; Gentile et all., 2007; Kurtz and Boone, 2010). Accordingly, consumers' behaviors change in this evolution. Nowadays, they don't seek only functional benefits but they relate to products as a result of their feelings towards them (Schmitt, 1999). Considering this change, as a competitive advantage, experiential marketing focuses on the emotional sides in addition to the customers' rational sides in order to create positive and memorable customer experiences (Schmitt, 1999; Berry et all., 2002; Meyer and Schwager, 2007; Shaw, 2007; McCarthy and Ciolfi, 2008; Yalçın, 2009; Dirsehan, 2010). This study considers customer experiences from museum perspective and focuses on the differences between customers with different experiential appeals in terms of their post experience dimensions.

\section{Museum Experiences}

The museums are institutions that keep alive the cultural assets of societies. In the 20th century, museums often concerned with collection and research than visitor-orientation. In recent years, museums compete increasingly with other leisure and educational institutions such as different cultural museums for visitors (Lehn, 2006; 
Bergadaà, 2005). Some examples of these institutions can be indicated as theatres, movie theatres, malls, circuses and amusement parks. So, museums need to compete with them using marketing strategies and they focus more and more on attracting visitors. This situation creates a shift from traditional "curators' dictation" to "visitor orientation". Therefore, museum managers need a change for their marketing strategies. Accordingly, museums today are expected to focus on visitors rather than to tell the public from curators' point of view (Rowley, 1999; Goulding, 2000; Harrison and Shaw, 2004; Lehn, 2006; Chang, 2006). In this way, the need to understand the museum experience has gained ground (Goulding, 2000).

The researches in the museum marketing area mainly focus on visitor profiling including demographics such as age, education, place of residence and nationality in order to determine who visits the museums (Harrison and Shaw, 2004). For instance, it's often found that a strong correlation exists between the socio-economic class of a visitor and the habit of museum visiting (Kawashima, 1998). But in today's competitive environment, the focus of museums marketing techniques shape the messages about the products and experiences delivered by museums (Caldwell, 2000). In recent years, audience research is increasingly focused on visitor experiences and learning (Kelly, 2004). In terms of visitor studies, the focus is often the educational role of museums and the learning outcome of museum visits while ignoring other aspects of the museum experience (Lehn, 2006).

The recent researches on museum consumer behavior reveal that museum visits are not anymore a simple informative cultural visits, but they are experiences (Falk and Dierking, 1992; Prentice et all., 1997; Kawashima, 1998; Goulding, 1999; Rowley, 1999; Goulding, 2000; Thyne, 2001; Bollo, 2004; Hume et all., 2006; Rojas and Camarero, 2006; Slater, 2007; Bifulco and Ilario, 2007; McCarthy and Ciolfi, 2008; Chan, 2009). The concept of experience becomes a key leading to consumer satisfaction. Consumers seek a "total experience", where leisure, culture, education and social interaction could be included (Rojas and Camarero, 2006). Related with their role of service experience consumption, museums can be defined as experience-centered places that offer both emotional and cognitive stimuli. Thus, understanding of visitor experiences is vital for museums focusing on visitors and experiences (Chan, 2009) and they are important assets for policy analysis and managerial implications (Yucelt, 2000).

\section{Insert Figure 1}

Especially, scientific museums develop immersive technologies offering virtual reality tools such as infrared headsets, 3D imagery, virtual reconstruction and stereoscopic glasses to immerse visitors in a particular environment and offer them an intense and memorable experience (Lachaud and Passebois, 2008; Belaën, 2003). Besides, RFID technologies increasingly take place in museums to create new experiences. For instance, RFID application in Exploratorium (a hands-on science museum in San Francisco) is based on an RFID card given to visitors at the start of the museum tour. Visitors approach to an exhibit, hold the card in the vicinity of a package and the ID number is recorded by the system, and then the visitor at its personal website views the dates of visit, the exhibits visited and the photographs taken. So visited exhibits are bookmarked and web based activities link related exhibit concepts on Web pages. Thereby, learning continues beyond the physical museum and without hurried-visitor problem (Hsi and Fait, 2005).

\section{Customer Experiences}

Businesses may have competitive advantage with their understanding of the customers' needs and paying attention to the customer value (Chou, 2009). They should consider also that in some instances, emotional desires dominate utilitarian motives in the choice of products (Hirschman and Holbrook, 1982: Maslow, 1968). The notion of experience has become a key element to understand consumer behavior and it's the basis of experiential marketing (Carù and Cova, 2006). Today, the experience is considered as a key concept in consumer culture theory (Arnould and Thompson, 2005). It has become the basis for experience economy (Pine and Gilmore, 1999), and then experiential marketing is developed (Schmitt, 1999) proposing differentiation with experiences rather than commoditized goods and services.

In terms of consumer - organisation interaction, the consumption experience is a response to a corporate stimulus taking forms of sensory, affective, creative cognitive, physical and social identity (Zarantonello, 2008). From a business perspective, "experiences are events that engage individuals in a personal way" (Pine and Gilmore, 1999, p.12). On the other hand, from a consumers perspective, "experiences are enjoyable, engaging, memorable encounters for those consuming these events" (Oh et al., 2007, p.120).

An experience is actually a new category of offering which is added to goods, products and services to constitute a forth category of offering adapted particularly to postmodern customer needs (Carù and Cova, 2006). As we know, there are three levels of product (Kotler et all., 1999): core product (core benefits that consumers are really buying), actual product (a product's attributes that combine to deliver core product benefits such as design, brand 
name, packaging) and augmented product (additional consumer services and benefits). Based on the experiences' ability to differentiate the products and services (Carbone and Haeckel, 1994; Schmitt, 1999; Carù and Cova, 2006), it can be possible to build a fourth level around the core, the actual and the augmented product as "experienced product" representing customer experiences which are sensory, affective, creative cognitive, physical and social identity experiences (Schmitt, 1999).

\section{Insert Figure 2}

As a tool to create a competitive advantage, experiential marketing which is an emerging concept in the field of marketing aims to create positive and memorable customer experiences to create an emotional tie with customers. It does not ignore the traditional marketing; in fact, experiential marketing is the complementary for it.

Beyond different demographic groups, Zarantonello and Schmitt (2010) offer five types of consumers based on different experiential appeals. These groups of consumers are holistic consumers (who are interested in all aspects of experience), hedonistic consumers (who attach importance to sensory and affective dimensions), action-oriented consumers (who focus on physical actions and behaviors), inner-directed consumers (who focus on internal processes which are sensations, emotions and thoughts) and utilitarian consumers (who are low-experiential consumers) (Zarantonello and Schmitt, 2010).

\section{The Place of Experiences in the Consumer Decision Making}

Services decision includes differences from goods decision making. Services are high in experience and credence qualities relative to goods. Three broad stages of consumer behavior for services are consumer choice (including need recognition, information search, evaluation of alternatives, purchase), consumer experience and post experience evaluation. Due to risky nature of services containing many unknowns, the experience itself often dominates the evaluation process. All services are experiences; some of them are long in duration some are short; some of them are complex, some are simple; some are commons, some others are exciting. The customer experience is the heart of services marketing and management, thus, creating and managing the experiences are essential management tasks for service organizations (Zeithaml et all, 2009).

\section{Insert Figure 3}

Post purchase and post experience evaluations of customers are generally most important to predict following consumer behaviors and repurchase especially for services. Post experience evaluation is measured by companies in terms of satisfaction, service quality, loyalty and sometimes emotional engagement (Zeithaml et all, 2009).

\subsection{Customer Satisfaction}

Satisfaction is the customer's evaluation of a product or service whether that product or service has met the customer's needs and expectations. Failure to meet needs and expectations is assumed to result in dissatisfaction with that product or service (Zeithaml et all, 2009). In other words, if the performance is over expectations, a positive disconfirmation is produced and an increase in satisfaction level is expected (Rojas and Camarero, 2006). Customer expectations can be shaped by customers' previous experiences, their personal situation, market conditions and the competition. In terms of customer experiences, the customer satisfaction can be defined as the net result of the good ones minus the bad ones (Meyer and Schwager, 2007). Considering the gap between the consumption experience and prior expectations, as mentioned before, the satisfaction is (Oliver, 1981: 27):

"The summary psychological state resulting when the emotion surrounding disconfirmed expectations is coupled with the consumer's prior feelings about the consumption experience."

Satisfaction is a significant antecedent for the post-purchase attitude, the intentions of repurchase and other good behavioral intentions (Cronin and Taylor, 1992; Fornell, 1992; Anderson and Sullivan, 1993; Zeithaml et all., 1996; Jones and Suh, 2000; Rojas and Camarero, 2006).

\subsection{Repurchase Intention}

Customer satisfaction is important for consumers' repurchases. If a consumer is satisfied with a product of a certain company, generally that consumer buys the product again, intends to promote it to other people, ignores competitors' brands' advertisements and stops to purchase from competitors (Chou, 2009). Repurchase intention is often confused with loyalty. Loyalty is the commitment to repurchase a particular product or service over time, while repurchase intention is the intention to engage of re-buying in the actual behavior (Hume et al., 2006). However, loyalty, a consequence of satisfaction in the business field is not a priority for cultural organizations since the purpose is not that the visitor repeats the visit too often. So, other results of satisfaction are important such as word of mouth communication, the recommendation of services and the intensification of its use (Rojas 
and Camarero, 2006).

\subsection{Word-of-Mouth Recommendation}

As mentioned before, a satisfied customer intends to promote the product to other people. Moreover, service consumers are influenced by other people's opinions. Hence, understanding word-of-mouth communication and its control are important for service offering companies (Zeithaml et all, 2009). Satisfaction from a previous experience with the service becomes positive word of mouth communication about the company (Bearden and Teel, 1983; Woodside et all., 1989; Zeithaml et all., 1996; Rojas and Camarero, 2006). The best way to get positive word of mouth is to create memorable and positive service experiences (Zeithaml et all, 2009).

The average customer having a problem tells 9 or 10 others about it (Evans, 1997). Similarly, as stated in the study of Harrison and Shaw (2004) on museums, satisfied visitors intend to recommend to other people. Thus, museums should consider implementing memorable and positive experiences not only for customer satisfaction but also for positive word of mouth communication.

\subsection{Intensification of the Visit}

When comparing with long-term behavioral intentions such as loyalty, consumers have also immediate behavioral responses referring to consumers' efforts to tangibilize the experience such as purchase of souvenirs and gifts (Bigné et al., 2008). As one of the visitor's satisfaction results, the intensification of the visit can be defined as an interest or motivation by the visitor or as a behavioral intention including the purchase of publications, souvenirs and presents. Satisfied visitors intensify their experience during the service and they purchase concrete materials connected to the visit (Rojas and Camarero, 2006). Thus, museum managers should consider the materials to sell in order to intensify the visitors' experience. As mentioned before, tangible takeaways such as programmes, souvenirs, prints and gifts are used in creating memorable experience. More innovative, personalized, customized memorabilia will enhance their value (Petkus, 2004).

\subsection{Learning in Museums}

Curators or producers of arts events often underestimate the desire of target audience to attain the knowledge about the work. An increased education dimension of the audiences becoming involved in the arts and repeating and expanding their patronage (Petkus, 2004).

Profit-oriented firms generally use financial measures to evaluate their performance. However, a non-profit organization's performance is measured in financial and nonfinancial terms, in other words, raising the funds and educating the public (Mottner and Ford, 2005). Different kinds of museums promote different kinds of learning paying attention to knowledge gain and thinking (Donald, 1991). Museums, art galleries, botanical gardens, national parks, science centers, zoos, aquaria and historic sites are important institutions for their public learning role, however, it cannot be assumed that all the visitors of these institutions come there to learn something, a large percentage of visitors are there to kill time, to be entertained, to satisfy curiosity (Packer and Ballantyne, 2002).

Museums should stimulate the desire to know (Donald, 1991). They attract visitors who are motivated to learn, who perceive the museum as a place where important information is provided in an interesting way, who are willing to devote effort to learning activities, and who find such efforts satisfying (Packer and Ballantyne, 2002). Experiential learning may be applied in museums by interesting offerings. As an example, visitors are surprised when traditional rules of museums are not applied, for instance, it is possible for them to touch and open the drawers, and to get closer to their contents in Study Collection Room of Hunt Museum located in Limerick, Ireland (Ciolfi and Bannon, 2002). Close contact with museum artefacts are beneficial for informal learning within museum (McCarthy and Ciolfi, 2008). Participants handling real museum objects experience great pleasure in exploring the materials of them, feeling their weight and manipulating them thinking about their past owners. Various workshop activities are also parts of learning in museums (Ciolfi and Bannon, 2002). Furthermore, immersive information communication technologies are used not only to create a memorable experience but also to facilitate knowledge arising curiosity (Lachaud and Passebois, 2008). Another system used by museums to extend learning along with to create experiences is RFID technology as mentioned before. It offers a way to learn beyond the museum by offering on personalized web pages, information about recorded exhibits during the visit (His and Fait, 2008). So, the environments offering experiences encourage individuals to act on, explore, manipulate, sort and describe the phenomena they investigate. These museums give opportunities for visitors to explore concepts in math, science, art, music, history and social studies (Henderson and Atencio, 2007).

Related with the personal nature of experiences, museums should facilitate quality learning experiences 
maximizing visitors' personal contexts of learning and considering social learning experiences, museums should facilitate them, encouraging and fostering social interactions with other visitors and museum staff (Chang, 2006). Hoch (2002) states four reasons to clarify that learning from experience is more seductive than learning from education. Firstly, experience is more engaging than education since it is more vivid and international. Secondly, experience is often private, not reproduced in the same form for anyone else. Thirdly, experience offers ambiguous evidence. Fourthly, experience is endogenous which increases the difficulty in predicting changes in preferences (Hoch, 2002).

\section{Classification of Museums}

Classification of museums in Turkey and in the world is shaped considering their different aspects. It can be based on their contents, on their civilizations and on their eras. The classification of museums according to their contents includes anthropological museums (archaeological, ethnographic, folkloric); history museums (social history, war, migration); art museums and modern art museums; natural art museums and nature museums; science, technical and industry museums and museums according to their specializations (tree, automobile, wine, health, tobacco, textile, toy etc.). The classification of museums according to their civilizations include Hittite civilization museum, Roman period museum, Byzantine period museum, Turkish-Islamic civilizations museums, Ottoman civilization museums and Republic period museums. The classification of museums according to their eras include museums according to their pieces' eras, museums concerning prehistory eras, museums concerning Lycia period, museums concerning Hellenistic era, museums concerning Neolithic era and museums concerning modern age (Bilgin, 2010).

Another categorization of museums is based on the theory of education consisting of theory of knowledge and theory of learning. Firstly, theory of knowledge can be represented as a continuum since it involves a dichotomy whether we believe that knowledge exists independently of the learner, as an absolute, or whether we subscribe to the view that knowledge consists only of ideas constructed in the mind. The second element which is theory of learning includes two possible extreme positions. A view is associated with the belief that the original condition of the mind is a tabula rasa and that all that is known has been acquired through experience. The best proponent of this view is Locke. The opposed view states that the mind constructs schemas and that learning consists of selecting and organizing from the abundance of sensations surrounding us. The combination of these two dimensions (theory of knowledge and theory of learning) generates a diagram. The four quadrants produced can be used to classify museums by their educational positions: systematic museums, discovery museums, orderly museums and constructivist museums (Hein, 1999).

\section{Insert Figure 4}

Distinctively from mentioned bases of classifications for museums, an experiential perspective can be applied to categorize museums. As mentioned before, museums provide experiences by nature, especially the social interaction. However, they should go beyond to be differentiated by experiences. So, it's possible to categorize them as dynamic museums in experience and museums static in experience. In this context, museums using experience as a competitive tool can be considered in the group of dynamic museums in experience. Oppositely, museums offering their natural experience and not improving it to create differentiation may be considered as static museums in experience. The museums which are static in experience are museums that offer always the same experience to their visitors. So, they do not offer dynamic experiences created by museum managers. The offered experience is the same but this experience is different for every customer due to the interactive nature of the experience as stated before. On the other hand, the museums considered as dynamic in experience compete with their experiences which change by museums' marketing strategy. These museums try to offer new experiences to their visitors considering their feedback. So, dynamic situation is created by museum experiences. The museums dynamic in experience are new in Turkey and general information about them is provided in the part of museums in Turkey in this study.

\section{Insert Table 1}

It's important to notice that some experiences are offered against fee in museums. For instance, listening information about the museum offerings with earphones is generally charged. Hence, two people may have different experiences after visiting the same museum basing on the choice of use of earphones. Even though two people use earphones during their visit, they have different experiences since experiences are personal as mentioned before.

\section{Museums in Turkey}

In Turkey, museums appeared primarily as modern institutions as indicator of westernization efforts in 19th 
century, aiming the conservation of rich, historical and cultural heritage. However, after 1930s, museums in Turkey fell behind against those in the West in terms of variety in the collection, new exhibition and expression methods and social sharing. At the beginning of Turkish museology and in the first years of the Republic, museum collections mainly consisted of archaeological, historical, ethnographic, crafts and Islamic arts monuments (Özkasım and Ögel, 2005).

In Turkey, there are a total of 295 museums related to Ministry of Culture and owned by people and institutions while there are 17.500 museums in USA. Among main competitors of Turkey in term of tourism, there are 3.790 museums in Italy, 1.343 museums in Spain and 1.207 museums in France according to the research of Association of Turkish Travel Agencies (Radikal, 2008, www.radikal.com.tr).

According to Ministry of Culture and Tourism data on museum visitors, there were 25881558 visitors for museums in Turkey in 2010.

\section{Insert Figure 5}

In our research, eight museums in Turkey which are dynamic in experience are used: Magic Ice Museum, 1453 Panorama Museum, Istanbul Toy Museum, Sakıp Sabancı Museum, Rahmi M. Koç Museum, Pera Museum, Istanbul Museum of Modern Art and Miniaturk.

\section{Research Methodology}

The sampling design process consists of five steps; defining the target population, determining the sampling frame, selecting a sample technique, determining the sample size and executing the sampling process (Malhotra, 2007).

In Turkey, there is no a center where all statistical information are collected about all museums in Turkey. So, the exact information about museum visitors in Turkey is not available. However exploratory study with museum managers reveals that the main target markets are students, however other people also are considered as secondary target markets. So, in this study, students' number is higher than the other occupation groups. In this study, the categorization of museums based on customer experiences is used. According to this categorization, there are two groups of museums; museums dynamic in experience (using experience as a competitive tool) and museums static in experience (offering the natural experience and not improving it to create differentiation). Target population in this study can be defined as visitors of museums dynamic in experience (Magic Ice Museum, 1453 Panorama Museum, Istanbul Toy Museum, Sakıp Sabancı Museum, Rahmi Koç Museum, Pera Museum, Istanbul Modern Art Museum and Miniaturk) in Istanbul, visited these museums in the past one year (November 2009 - November 2010). Sampling frame of this study is students and other people from other occupation groups who have visited museums dynamic in experience in the past one year in Istanbul.

In terms of sample technique, convenience sampling and snowball sampling, which are nonprobability techniques are used in this study. Convenience sampling is used to obtain a sample of convenient elements; it's the least expensive and least time consuming sampling technique. In snowball sampling, subsequent respondents are selected based on the information by the initial randomly selected respondents; its main advantage is that it increases the probability of locating the desired characteristic in the population (Malhotra, 2007). These two sampling techniques are preferred due to the time and budget constraints of this study.

Cochran (1963, p.75) developed an equation to determine sample size for large populations (Israel, 2009). The following equation indicates 385 people for this study with a $95 \%$ confidence level and $\pm 5 \%$ precision as shown with the following calculation:

$$
n=\frac{\mathrm{z}^{2} p q}{e^{2}}=\frac{(1.96)^{2}(0.5)(0.5)}{(0.05)^{2}}=385 \text { people. }
$$

However, the sample size for this study is decided considering the use of structural equation modeling. A typical sample size in structural equation modeling used studies is about 200 cases, however when analyzing a complex model, a sample size of 200 may be too small (Kline, 2010). Multiplying the number of variables by 8 to 15 is enough for a sample size in analysis with structural equation modeling (Acar et al., 2009). According to Kerlinger (1978), sample size should be at least 10 multiplying by variables in the study. So, the sample size for this study is determined by multiplying observed variables to be used in the structural model by ten. Based on this information, in this study with 46 observed variables (item numbers between 9 and 54), a sample size of 460 is decided. As a result, 460 questionnaires were collected between 10th October 2010 and 5th November 2010 by respondents who visited at least one museum dynamic in experience in the past one year in Istanbul.

Based on literature review, exploratory research and pretest, a questionnaire is designed to collect primary data 
through quantitative research. Data were gathered from respondents in Istanbul between 10th October 2010 and 5th November 2010. The questionnaires of respondents who have not visited the museums indicated are excluded from the study and a total of 460 questionnaires are used in data analysis.

The questionnaire used in the study includes four main parts. The first one is the filtering part. The first and the second questions are filter questions. The questionnaire is excluded from the study if the respondent has not visited a museum in last one year or visited a museum other than those indicated in the second question. Other respondents continue to the following questions choosing a museum according to their satisfaction degree in the third question. The second part of the questionnaire covers the questions between fourth and eighth questions which are related with visitors' museum visiting habits. The third part includes the questions to measure museums visitors' customer experiences (sensory, affective, creative cognitive, physical and social identity experiences), learning in museum, satisfaction, intensifying of visit; revisit intention and word-of-mouth recommendation. This part is formed by structured questions and measured on a Likert scale basis. The response categories of this scale are "Strongly Disagree", "Disagree", "Neither Agree nor Disagree", "Agree", "Strongly Agree".

The statistical programs used to analyze the data obtained from questionnaires are SPSS Statistics 17 for Windows and LISREL 8.80 for Windows. SPSS is used to analyze reliabilities, descriptions, frequencies, clusters, differences of means (t-tests and ANOVA) and LISREL is used to generate structural equation modeling including confirmatory factor analyses and relationships between variables.

\section{Research Findings}

The research findings can be grouped in three subtitles. Firstly, the items measuring customer experiences are analyzed with confirmatory factor analysis. Secondly, a confirmatory factor analysis is conducted for post experience dimensions (learning in museum, visitor satisfaction, visit intensifying, revisit intention and WOM recommendation). Thirdly, the difference between clusters of visitors based on customer experiences is analyzed. All the analyses are conducted with a $95 \%$ confidence level.

\subsection{Confirmatory Factor Analysis for Customer Experience}

Factor analysis is conducted to reduce the number of variables into significant factors bringing together highly correlated variables (Kalayc1, 2008). Factor analysis is an interdependence technique in which a set of interdependent relationships is examined (Malhotra, 2007). Two types of factor analyses are confirmatory factor analysis and exploratory factor analysis. The main difference between them is that confirmatory factor analysis is used to analyze a priori measurement model with the specified number of factors and their correspondence with the indicators basing on theory (Kline, 2010; Şimşek, 2007). However, a priori hypothesis about factor-indicator correspondence or the number of factors are not necessaries for exploratory factor analysis (Kline, 2010). Structural equation modeling with LISREL program is used to conduct confirmatory factor analyses (CFA) in this research.

The aim to conduct CFA is to analyze the relationships of observed variables (items used in the questionnaire) with latent variables which are customer experiences (sensory, affective, creative cognitive, physical, social identity) and post experience dimensions (learning in museum, satisfaction, visit intensifying, revisit intention, word-of-mouth recommendation).

For customer social identity experience, one item is excluded due to its weak factor loading comparing to others. In confirmatory factor analyses, it is recommended to have at least three indicators per factor (Kline, 2010). Thus, customer social identity experience with two items is excluded from structural equation analyses. CFA is conducted for the rest four kinds of customer experiences.

The results of the initial estimation of the first level CFA for customer experiences are not acceptable since there is a Chi-square value of 407.71 with 113 degrees of freedom even though RMSEA value (0.075), NFI value $(0,95)$, NNFI value $(0.96)$, CFI value $(0.96)$, AGFI value $(0.87)$, SRMR value $(0.054)$ shows acceptable fits. Some items are eliminated because of low t-values, high standard error, low explained variances and relatively less important variables as indicators of each customer experience. After deleting some items, the first-level CFA is conducted again. The fit measures indicate that the model is acceptable (Chi-square $=132.99$; $\mathrm{df}=48$; $\mathrm{RMSEA}=0.062 ; \mathrm{NFI}=0.97 ; \mathrm{NNFI}=0.97 ; \mathrm{CFI}=0.98 ; \mathrm{AGFI}=0.93 ; \mathrm{SRMR}=0.041)$.

\section{Insert Figure 6}

\subsection{Confirmatory Factor Analysis for Post Experience Dimensions}

The results of the initial estimation of the first level CFA for customer experiences are not acceptable since there 
is a Chi-square value of 1131.04 with 289 degrees of freedom in addition to AGFI value (0.81), even though RMSEA value (0.08), NFI value $(0,97)$, NNFI value $(0.97)$, CFI value $(0.97)$, SRMR value $(0.07)$ shows acceptable fits. Some items are eliminated because of low t-values, high standard error, low explained variances and relatively less important variables as indicators of each customer experience. After deleting these items, each construct has three observed variables and the first-level CFA is conducted again. The fit measures indicate that the model is acceptable (Chi-square $=166.93 ; \mathrm{df}=80 ; \mathrm{RMSEA}=0.049 ; \mathrm{NFI}=0.98 ; \mathrm{NNFI}=0.99 ; \mathrm{CFI}=0.99$; AGFI $=0.93$; SRMR $=0.031$ ).

Insert Table 2 and 3

\subsection{Differences between Clusters Based on Customer Experiences}

The means of respondents for sensory, affective, creative cognitive and physical customer experiences (using the items based on confirmatory factor analysis) are used as clustering variables (referring to confirmatory factor analysis results). Cluster analyses are run to identify appropriate number of clusters. On the basis of dendrograms, the two-cluster solution is chosen as the most appropriate one. These two clusters have similar characteristics with holistic consumers and utilitarian consumers which are named by Zarantonello and Schmitt (2010).

First cluster of our study includes respondents with the highest scores on all experiential dimensions, so they are called holistic consumers. Second cluster consists of respondents with the lowest scores on all experiential dimensions, so they are called utilitarian consumers. Accordingly, holistic museum visitors are most interested visitor group in all types of experiences and they have higher experiential appeals than those of utilitarian museum visitors.

From a total of 460 participants to this study, 318 respondents are holistic museum visitors and the rest, 142 respondents are utilitarian museum visitors. In addition to their difference in terms of experiences, it's also analyzed their difference in terms of post experience dimensions (learning in museum, visitor satisfaction, visit intensification, revisit intention, word-of-mouth communication). Fifth experience dimension, social identity experience is also used (the mean of two variables are used for this dimension as used in testing the hypotheses about mean comparisons between groups). The results reveal that holistic museum visitors have higher ratings for all post experience dimensions than those of utilitarian museum visitors. This result imply that, comparing with utilitarian museum visitors; holistic museum visitors are more satisfied, they learn more in museum, they tend to intensify more their visit, they intend more to revisit the museum and they tend to recommend the museum to others.

Insert Figure 7,8 and Table 4

\section{Conclusion}

Marketing development has several stages in the history. This evolution is mainly based on the increasing competitive environment for all sectors. Accordingly, marketing strategies are progressed from production-focus to visitor-focus, in other words, from inside capacities to outside capabilities. Relationship marketing, the today's era, indicates the importance of building strong relationships with consumers. An organization may satisfy more its customers with more capabilities to create a link between them and this link is not only functional but also emotional. Considering emotions in addition to consumer's rational sides, experiential marketing proposes to enhance customer experiences to achieve a differentiating competitive advantage.

It's obvious that services offer by nature more experiences than goods and this study uses the museum perspective to analyze customer experiences. Museums are classically defined as institutions that brings cultural heritage to people. However, it's important to notice that, in recent years, they compete with other leisure and educational institutions. Thus, museums evolve from a classical assets-focus to a visitor-focus. Nowadays, they offer more experiences to their visitors than they have done before. So, a new categorization is possible for museums; museums dynamic in experience (using experience as a competitive tool) and museums static in experience (offering the natural experience and not improving it to create differentiation). Even though customer experience management has gained ground for museum marketing strategies in the competitive environment, this progress is in the beginning stage and especially in Turkey, there are a limited number of museums which are dynamic in experiences.

Museum managers should know the visitors. Beyond the segmentation according to demographic characteristics, this study identifies two groups of museum visitors. Utilitarian museum visitors have low-experiential appeals, in the contrary holistic visitors are interested in all experience types. In addition, the ratings of utilitarian consumers are lower than the ratings of holistic consumers for all post experience dimensions (learning in 
museum, visitor satisfaction, visit intensification, revisit intention and word-of-mouth recommendation). Thus, museum marketing managers should segment their visitors according to their experiential appeal and offer more experiences to holistic consumers. Thereby, holistic consumers can be more satisfied and they may have more positive post experience attitudes. In general, science museums use different technologies such as RFID or information technologies to enhance visitor experiences. These applications should be expanded to other types of museums in order to develop visitor experiences which lead to positive post experience attitudes.

In terms of the implications for academicians, the results indicate a new clustering approach for museum visitors beyond the demographic characteristics and show the differences between utilitarian and holistic visitors with museum perspective. Future studies may be conducted with other museums in different cities or countries and also in different sectors to explore more consumer types and more differences between them.

This study has several limits. Since this research is conducted for museums dynamic in experience in Turkey, the results of the model and the clusters based on customer experiences may vary depending on different sectors and different countries. This study is expected to be beneficial for museums' strategies and future studies on customer experiences.

\section{References}

Acar, F., \& A. Oğuzlar ve S. Tüzüntürk. (27-29 May, 2009). Bayesgil Yapısal Eşitlik Modelleri ve Bir uygulama Örneği. 10th Econometrics and Statistics Symposium. Erzurum.

Anderson, E. W., and M. W. Sullivan. (1993). The Antecedents and Consequences of Customer Satisfaction for Firms. Marketing Science, 12.2, 125-143. http://dx.doi.org/10.1287/mksc.12.2.125

Arnould, E. J., and C. J. Thompson. (2005). Consumer Culture Theory (CCT): Twenty Years of Research. Journal of Consumer Research, 31, 868-882. http://dx.doi.org/10.1086/426626

Bearden, W. O., and J. E. Teel. (1983). Selected Determinants of Consumer Satisfaction and Complaint Reports. Journal of Marketing Research, 20, 21-8. http://dx.doi.org/10.2307/3151408

Belaën, F. (8-12 September 2003). L'Immersion au Service des Musées des Sciences. 7th International Cultural Heritage Informatics Meeting. Paris : Ecole du Louvre, 1-17.

Bergadaà, M. (3-6 July 2005). Le Musée Olympique: La Structuration d'un Objet Culturel à Caractère Universel à 1'Aide d'Enquêtes Qualitatives. 8th International Conference on Arts and Cultural Management. Montréal: AIMAC.

Berry, L. L., L. P. Carbone, and S. H. Haeckel. (2002). Managing the Total Customer Experience. MIT Sloan Management Review, 43, 3, 1-6.

Bifulco, F., and A. Ilario. (5-6 Ottobre 2007). Il Consumatore Culturale Experience-Driven: Evidenze di Fruizione del Sistema Museale Napoletano. IV Convegno Annuale Soicetà Italiana Marketing: Marketing dei Talenti, 1-20. Roma.

Bigné, J. E., A. S. Mattila, and L. Andreu. (2008). The Impact of Experiential Consumption Cognitions and Emotions on Behavioral Intentions. Journal of Services Marketing, 22, 4, 303-315. [Online] Available: http://dx.doi.org/10.1108/08876040810881704

Bilgin, G. (2010). İstanbul Müzeleri. İstanbul: İstanbul Büyükşehir Belediyesi Kültür A.Ş. Yayınları.

Bollo, A. (2004). Indagine Sul Pubblico dei Musei Lombardi. Fondazione Fitzcarraldo. [Online] Available: http://www.fitzcarraldo.it/ricerca/pdf/musei_lombardia.pdf (12 August 2010).

Caldwell, N. G. (2000). The Emergence of Museum Brands. International Journal of Arts Management, 2, 3, 28-34.

Carbone, L. P., and S. H. Haeckel. (1994). Engineering Customer Experiences. Marketing Management, 3, 3, 9-19.

Carù, A., and B. Cova. (2006). Expériences de Consommation et Marketing Expérientiel. Revue Française de Gestion, 162, 99-113.

Chan, J. K. L. (2009). The Consumption of Museum Service Experiences: Benefits and Value of Museum Experiences. Journal of Hospitality Marketing \& Management, 18, 173-196.

Chang, E. (2006). Interactive Experiences and Contextual Learning in Museums. Studies in Art Education, 47.2, 170-186.

Chou, H. J. (2009). The Effect of Experiential and Relationship Marketing on Customer Value: A Case Study of 
International American Casual Dining Chains in Taiwan. Social Behavior and Personality, 37, 7, 993-1008.

Cochran, W. G. (1963). Sampling Techniques. (2nd Edition). New York: John Wiley and Sons, Inc.

Cronin, J. J., and S. A. Taylor (1992). Measuring Service Quality: A Reexamination and Extension. Journal of Marketing, 56, 55-68. http://dx.doi.org/10.2307/1252296

Dirsehan, T. (2010). Örneklerle Temel Deneyimsel Pazarlama. İstanbul : İkinci Adam Yayınları.

Dirsehan, T. (2011). "Romantic Movement in Marketing": The Effects of Customer Experiences on Post Experience Dimensions from the Museum Perspective. Unpublished Master Thesis. Marmara University Institute of Social Sciences.

Evans, J. R. (1997). Production/Operations Management. (5th Edition). St.Paul, MN: West Publishing Company.

Falk, J. H., \& L. D. Dierking. (1992). The Museum Experience. Washington, DC: Howells House.

Fornell, C. (1992). A National Customer Satisfaction Barometer: The Swedish Experience. Journal of Marketing, 56, 6-21. http://dx.doi.org/10.2307/1252129

General Directorate of Cultural Heritage and Museum. [Online] Available: http://www.kulturvarliklari.gov.tr/belge/1-45478/eski2yeni.html.

Gentile, C., N. Spiller and G. Noci. (2007). How to Sustain the Customer Experience: An Overview of Experience Components that Co-create Value With the Customer. European Management Journal, 25, 5, 395-410. http://dx.doi.org/10.1016/j.emj.2007.08.005

Goulding, C. (1999). Contemporary Museum Culture and Consumer Behaviour. Journal of Marketing Management, 15, 647-671. http://dx.doi.org/10.1362/026725799785037003

Goulding, C. (2000). The Museum Environment and The Visitor Experience. European Journal of Marketing, 34, 3/4, 261-278. http://dx.doi.org/10.1108/03090560010311849

Harrison, P., and R. Shaw. (2004). Consumer Satisfaction and Post-purchase Intentions: An Exploratory Study of Museum Visitors. International Journal of Arts Management, 6, 2, 23-32.

Hein G. (1999). The Constructivist Museum. In Greenhill E.H. (Ed.) The Educational of The Museum. (2nd Edition). London: Routledge, p77.

Hirschman, E.C., and M. B. Holbrook. (1982). Hedonic Consumption: Emerging Concepts, Methods and Propositions. Journal of Marketing, 46, 92-101. http://dx.doi.org/10.2307/1251707

Hsi, S., and H. Fait. (2005). RFID Enhances Visitors' Museum Experience at the Exploratorium. Communications of the ACM, 48, 9, 60-65. http://dx.doi.org/10.1145/1081992.1082021

Hume, M., G. S., Mort, P. W. Liesch and H. Winzar. (2006). Understanding Service Experience in Non-Profit Performing Arts: Implications for Operations and Service Management. Journal of Operations Management, 24, 304-324. http://dx.doi.org/10.1016/j.jom.2005.06.002

Israel, G. D. (2009). Determining Sample Size. University of Florida IFAS Extension. [Online] Available: http://edis.ifas.ufl.edu/PD006 (November 2, 2010).

Jones, M. A., and J. Suh. (2000). Transaction-Specific Satisfaction and Overall Satisfaction: An Empirical Analysis. Journal of Services Marketing, 14, 2, 147-159. http://dx.doi.org/10.1108/08876040010371555

Kawashima, N. (1998). Knowing the Public. A Review of Museum Marketing Literature and Research. Museum Management and Curatorship, 17, 1, 21-39. http://dx.doi.org/10.1080/09647779800301701

Keith, R. J. (1960). The Marketing Revolution. Journal of Marketing, 24, 35-38. http://dx.doi.org/10.2307/1248704

Kelly, L. (2004). Evaluation, Research and Communities of Practice: Program Evaluation in Museums. Archival Science, 4, 45-69. http://dx.doi.org/10.1007/s10502-005-6990-x

Kerlinger, F. N. (1978). Foundations of Behavioral Research. McGraw- Hill, New York.

Kline, R. B. (2010). Principles and Practice of Structural Equation Modeling. (3rd Edition). New York: The Guilford Press.

Kotler, N. G., P. Kotler and W. I. Kotler. (2008). Museum Marketing and Strategy: Designing Missions, Building Audiences. (2nd Edition). Generating Revenue and Resources. Jossey-Bass.

Kotler, P., G. Armstrong, J. Saunders, and V. Wong. (1999). Principles of Marketing. (2nd European Edition). 
New Jersey: Prentice Hall.

Kurtz, D. L., and L. E. Boone. (2010). Principles of Contemporary Marketing. (14th International Edition). South Western.

Lachaud, I. C., and J. Passebois. (2008). Do Immersive Technologies Add Value to the Museumgoing Experience? An Exploratory Study Conducted at France's Paléosite. International Journal of Arts Management, 11, 1, 60-71.

Lehn, D. V. (2006). Embodying Experience. European Journal of Marketing, 40, 11/12, 1340-1359. http://dx.doi.org/10.1108/03090560610702849

Malhotra, N. K. (2007). Marketing Research. (5th Edition). New Jersey: Pearson Education.

Maslow, A. H. (1968). Toward a Psychology of Being. (2nd Edition). N.J.: Van Nostrand.

McCarthy J., and L. Ciolfi. (2008). Place as Dialogue: Understanding and Supporting the Museum Experience. International Journal of Heritage Studies, 14, 3, 247-267. http://dx.doi.org/10.1080/13527250801953736

Meyer C., and A. Schwager. (2007). Understanding Customer Experience. Harvard Business Review, February 2007, 1-12.

Ministry of Culture and Tourism - T. C. Kültür ve Turizm Bakanlı̆̆ı Kültür Varlıkları ve Müzeler Genel Müdürlüğü. (t.y.) [Online] Available: http://www.kulturvarliklari.gov.tr (May 23, 2010).

Oh, H., A. M. Fiore, and M. Jeoung. (2007). Measuring Experience Economy Concepts: Tourism Applications. Journal of Travel Research, 46, November, 119-132. http://dx.doi.org/10.1177/0047287507304039

Oliver, R. L. (1981). Measurement and Evaluation of Satisfaction Processes in Retail Settings. Journal of Retailing, 57, 3, 25-48.

Özkasım, H., and S. Ögel. (2005). Türkiye‘de Müzeciliğin Gelişimi. İtü Dergisi/b - Sosyal Bilimler Serisi, 2, 1, 96-102.

Petkus E. Jr. (2004). Enhancing The Application of Experiential Marketing in The Arts. International Journal of Nonprofit and Voluntary Sector Marketing, 9, 1, 49-56. http://dx.doi.org/10.1002/nvsm.232

Pine II, B. J., and J. H. Gilmore. (1999). The Experience Economy: Work is Theatre \& Every Business a Stage. Boston, MA: Harvard Business School Press.

Prentice, R., A. Davies, and A. Beeho. (1997). Seeking Generic Motivations for Visiting and Not Visiting Museums and Like Cultural Attractions. Museum Management and Curatorship, 16, 1, 45-70. http://dx.doi.org/10.1080/09647779700501601

Radikal (2008). [Online] Available: www.radikal.com.tr.

Rojas, M. C., and M. C. Camarrero. (2006). Experience and Satisfaction of Visitors to Museums and Cultural Exhibitions. International Review on Public and Non Profit Marketing, 3, 1, 49-65.

Rowley, J. (1999). Measuring Total Customer Experience in Museums. International Journal of Contemporary Hospitality Management, 11, 6, 303-308. http://dx.doi.org/10.1108/09596119910281801

Schmitt, B. (1999). Experiential Marketing. Journal of Marketing Management, 15, 53-67. http://dx.doi.org/10.1362/026725799784870496

Shaw, C. (2007). The DNA of Customer Experience, How Emotions Drive Value. New York: Palgrave Macmillan.

Slater, A. (2007). Escaping to the Gallery: Understanding the Motivations of Visitors to Galleries. International Journal of Nonprofit and Voluntary Sector Marketing, 12, 149-162. http://dx.doi.org/10.1002/nvsm.282

Thyne, M. (2001). The importance of Values Research for Nonprofit Organisations: The Motivation-Based Values of Museum Visitors. International Journal of Nonprofit and Voluntary Sector Marketing, 6, 2, 116-130. http://dx.doi.org/10.1002/nvsm.140

TÜİK - Türkiye İstatistik Kurumu. [Online] Available: http://www.tuik.gov.tr/VeriBilgi.do?tb_id=15\&ust_id=5.

Woodside, A. G., L. L. Frey and R. T. Daly. (1989). Linking Service Quality, Customer Satisfaction, and Behavioral Intention. Journal of Health Care Marketing, 9, 4, 5-17.

Yalçın, M. (2009). İnovasyonla Hizmet ve Deneyim. İstanbul: Yaprak Yayın Dağıtım.

Yucelt, U. (2000). Marketing Museums: An Empirical Investigation Among Museum Visitors. Journal of Nonprofit \& Public Sector Marketing, 8, 3, 3-13. http://dx.doi.org/10.1300/J054v08n03_02 
Zarantonello L. (2008). L'adattamento della Brand Experience Scale al Mercato Italiano. Mercati e Competitività, 3, 109-132.

Zarantonello L., and B. H. Schmitt. (2010). Using the Brand Experience Scale to Profile Consumers and Predict Consumer Behaviour. Journal of Brand Management, 17, 7, 532-540. http://dx.doi.org/10.1057/bm.2010.4

Zeithaml, V. A., M. J. Bitner and D. D. Gremler. (2009). Services Marketing: Integrating Customer Focus Across The Firm. (5th International Edition). Singapore: McGraw Hill.

Table 1. Dynamic Museums in Experience with their Differentiating Experiences

\begin{tabular}{|c|c|}
\hline Museums & Examples of Differentiating Experiences \\
\hline Magic Ice Museum & $\begin{array}{l}\text { - Walking through and observing sculptures, walls and tunnels } \\
\text { made by ice. } \\
\text { - Sitting on tables made by ice. } \\
\text { - Drinking fruit juice from glass by ice. } \\
\text { - Having education sessions on ice sculpture. }\end{array}$ \\
\hline 1453 Panorama Museum & $\begin{array}{l}\text { - Watching the whole panoramic picture. } \\
\text { - Hearing different voices watching different part of the picture. } \\
\text { - Listening information about the museum offerings with } \\
\text { earphones. }\end{array}$ \\
\hline Istanbul Toy Museum & $\begin{array}{l}\text { - Sitting on train chairs and hearing train voices in train room of } \\
\text { the museum. } \\
\text { - Having red walls in fire-fighting room. } \\
\text { - Hearing particular voices for different rooms. } \\
\text { - Listening information about the museum offerings with } \\
\text { earphones. }\end{array}$ \\
\hline Sakıp Sabancı Museum & $\begin{array}{l}\text { - Having guidance. } \\
\text { - Having education sessions. } \\
\text { - Watching films related with the museum offerings. }\end{array}$ \\
\hline Rahmi M. Koç Museum & $\begin{array}{l}\text { - Having education sessions in studios. } \\
\text { - Participating to different weekend activities, for instance } \\
\text { nostalgic rides on railway along the shores of the Golden Horn. } \\
\text { - Trying out in some exhibits to be entertained and be informed. }\end{array}$ \\
\hline Pera Museum & $\begin{array}{l}\text { - Having education sessions. } \\
\text { - Watching films related with museum offerings. }\end{array}$ \\
\hline Istanbul Museum of Modern Art & $\begin{array}{l}\text { - Having education sessions. } \\
\text { - Participating to special organizations. }\end{array}$ \\
\hline Miniaturk & $\begin{array}{l}\text { - Observing different models of monuments from Turkish and } \\
\text { Ottoman geography. }\end{array}$ \\
\hline
\end{tabular}

Table 2. Correlation Matrix of Post Experience Dimensions

\begin{tabular}{|l|c|c|c|c|c|}
\hline & $\begin{array}{c}\text { Learning in } \\
\text { Museum }\end{array}$ & $\begin{array}{c}\text { Visitor } \\
\text { Satisfaction }\end{array}$ & $\begin{array}{c}\text { Visit } \\
\text { Intensifying }\end{array}$ & $\begin{array}{c}\text { Revisit } \\
\text { Intention }\end{array}$ & $\begin{array}{c}\text { Word-of-Mouth } \\
\text { Recommendation }\end{array}$ \\
\hline Learning in Museum & 1 & & & & \\
\hline Visitor Satisfaction & & 1 & & & \\
\hline Visit Intensifying & 0.32 & 0.35 & 1 & & \\
\hline Revisit Intention & 0.48 & 0.58 & 0.47 & 1 & 1 \\
\hline $\begin{array}{l}\text { Word-of-Mouth } \\
\text { Recommendation }\end{array}$ & 0.66 & 0.77 & 0.39 & 0.61 & 1 \\
\hline
\end{tabular}


Table 3. CFA Results for Post Experience Dimensions

\begin{tabular}{|c|c|c|c|}
\hline Latent Variable & Observed Variable & $\begin{array}{c}\text { Standardized } \\
\text { Coefficient Value }\end{array}$ & $\mathrm{R}^{2}$ \\
\hline \multirow{3}{*}{$\begin{array}{l}\text { Learning in } \\
\text { Museum }\end{array}$} & $\begin{array}{l}\text { I learn many things about the pieces in this } \\
\text { museum. }\end{array}$ & 0.72 & 0.53 \\
\hline & I learn new things in this museum. & 0.86 & 0.74 \\
\hline & I believe that this museum is educational for me. & 0.90 & 0.81 \\
\hline \multirow{3}{*}{ Visitor Satisfaction } & $\begin{array}{l}\text { I am sure it is the right decision to visit this } \\
\text { museum. }\end{array}$ & 0.84 & 0.70 \\
\hline & In general, I'm satisfied with this visit. & 0.87 & 0.75 \\
\hline & It's worthwhile to visit this museum. & 0.91 & 0.84 \\
\hline \multirow{3}{*}{ Visit Intensifying } & I shop at this museum's store. & 0.80 & 0.63 \\
\hline & $\begin{array}{l}\text { I take some things reminding me this museum } \\
\text { visit. }\end{array}$ & 0.62 & 0.39 \\
\hline & I take the brochure of this museum. & 0.89 & 0.79 \\
\hline \multirow{3}{*}{ Revisit Intention } & I plan to visit this museum again. & 0.89 & 0.79 \\
\hline & $\begin{array}{l}\text { I think to come back again to this museum in the } \\
\text { future. }\end{array}$ & 0.93 & 0.87 \\
\hline & I go to this museum again on occasion. & 0.83 & 0.69 \\
\hline \multirow{3}{*}{$\begin{array}{l}\text { Word-of-Mouth } \\
\text { Recommendation }\end{array}$} & I recommend this museum to others. & 0.91 & 0.84 \\
\hline & $\begin{array}{l}\text { I encourage my friends or relatives to come to } \\
\text { this museum. }\end{array}$ & 0.91 & 0.84 \\
\hline & $\begin{array}{l}\text { I take pride in telling other people about my } \\
\text { experiences in this museum. }\end{array}$ & 0.72 & 0.52 \\
\hline
\end{tabular}

Table 4. Differences between Clusters based on Customer Experiences

\begin{tabular}{|c|c|c|c|c|c|c|}
\hline & \multicolumn{4}{|c|}{$\begin{array}{c}\text { Visitors Clustered According to Their } \\
\text { Experiences }\end{array}$} & & \\
\hline & \multicolumn{2}{|c|}{ Holistic Consumers } & \multicolumn{2}{|c|}{$\begin{array}{l}\text { Utilitarian } \\
\text { Consumers }\end{array}$} & \multicolumn{2}{|c|}{ All Visitors } \\
\hline & $\bar{x}$ & $\sigma$ & $\bar{x}$ & $\sigma$ & $\bar{x}$ & $\sigma$ \\
\hline Sensory Experiences & 4.01 & 0.64 & 2.95 & 0.82 & 3.68 & 0.86 \\
\hline Affective Experiences & 3.94 & 0.55 & 2.70 & 0.67 & 3.56 & 0.82 \\
\hline Creative Cognitive Experiences & 4.10 & 0.52 & 3.06 & 0.67 & 3.78 & 0.75 \\
\hline Physical Experiences & 3.31 & 0.77 & 2.28 & 0.65 & 2.99 & 0.88 \\
\hline Social Identity Experiences & 2.72 & 0.96 & 2.12 & 0.72 & 2.53 & 0.93 \\
\hline Learning in Museum & 4.11 & 0.55 & 3.39 & 0.86 & 3.89 & 0.74 \\
\hline Visitor Satisfaction & 4.34 & 0.51 & 3.74 & 0.84 & 4.15 & 0.69 \\
\hline Visit Intensification & 3.60 & 0.80 & 3.17 & 1.05 & 3.47 & 0.90 \\
\hline Revisit Intention & 3.75 & 0.88 & 2.98 & 0.95 & 3.51 & 0.97 \\
\hline $\begin{array}{l}\text { Word-of-Mouth } \\
\text { Recommendation }\end{array}$ & 4.32 & 0.57 & 3.56 & 0.96 & 4.08 & 0.79 \\
\hline $\mathrm{N}$ & \multicolumn{2}{|c|}{318} & \multicolumn{2}{|c|}{142} & \multicolumn{2}{|c|}{460} \\
\hline
\end{tabular}




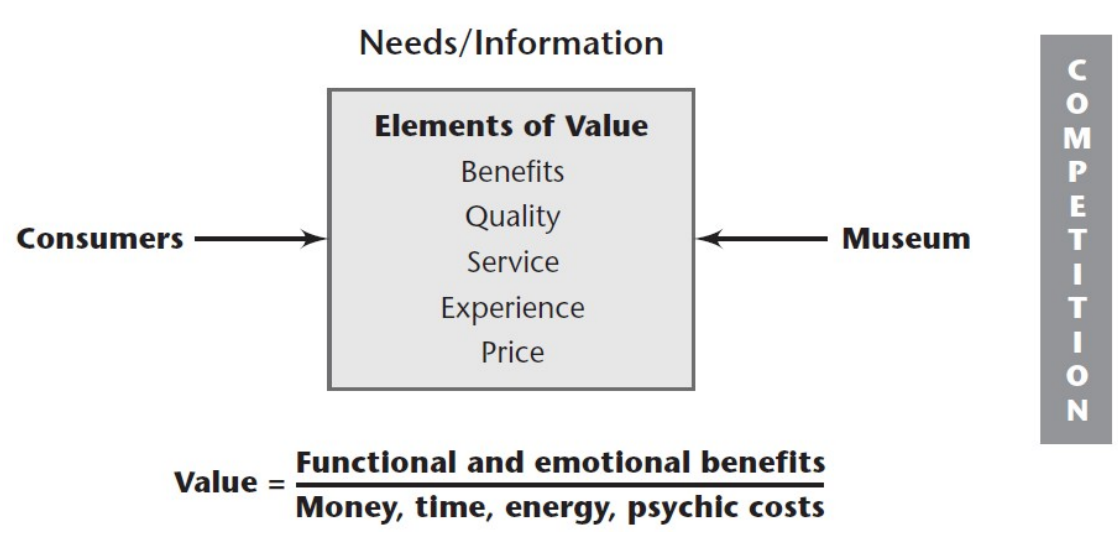

Figure 1. Museum Exchange Transactions and Relationships

Source: Kotler N.G., Kotler P. and Kotler W.I. (2008). Museum Marketing and Strategy: Designing Missions, Building Audiences, Generating Revenue and Resources. Jossey-Bass, 2nd Edition, p. 23.

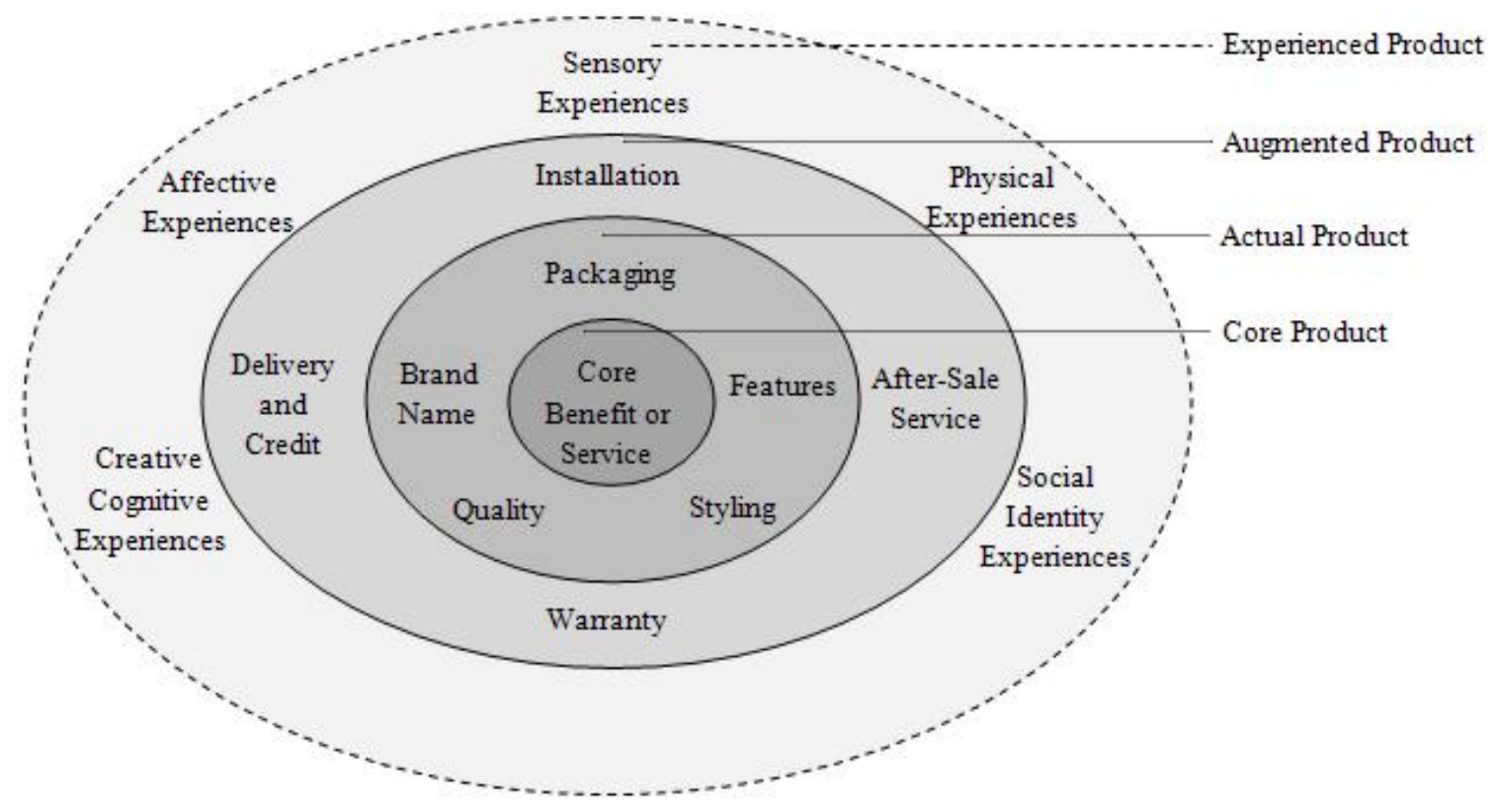

Figure 2. Contribution to the Levels of Product

Developed from: Kotler P., Armstrong G., Saunders J. and Wong V. (1999). Principles of Marketing. New Jersey: Prentice Hall, 2nd European Edition, p. 562; Schmitt B. (1999). Experiential Marketing. Journal of Marketing Management. 15, 53-67; Carbone L.P. and Haeckel S.H. (1994). Engineering Customer Experiences. Marketing Management. 3.3, 9-19; Carù A. and Cova B. (2006). Expériences de Consommation et Marketing Expérientiel. Revue Française de Gestion. 162, 99-113. 


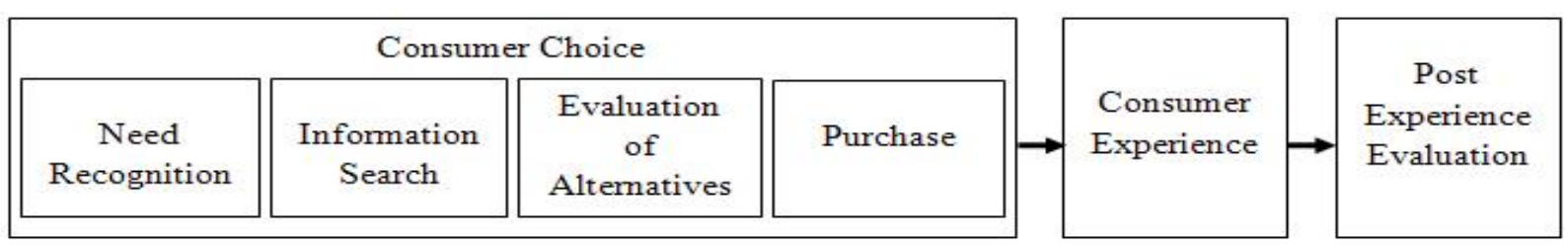

Figure 3. Stages in Consumer Decision Making and Evaluation of Services

Source: Zeithaml V.A., Bitner M.J. and Gremler D.D. (2009). Services Marketing: Integrating Customer Focus Across The Firm. Singapore: McGraw Hill, 5th International Edition, p. 51.

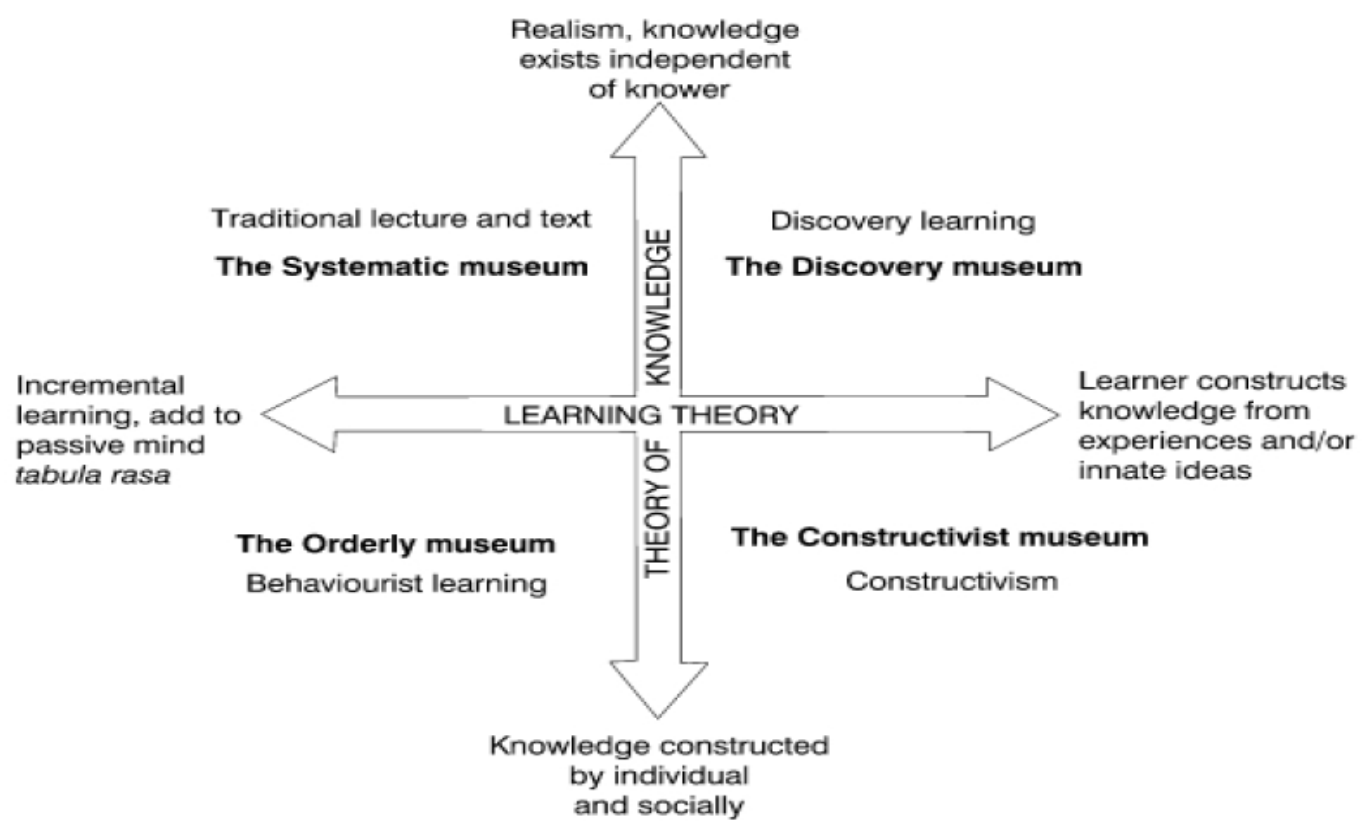

Figure 4. Classification of Museums Based on Educational Theory

Source: Hein G. (1999). The Constructivist Museum. In Greenhill E.H. (Ed.) The Educational of The Museum (2nd Edition, pp. 73-79). London: Routledge, p. 77.

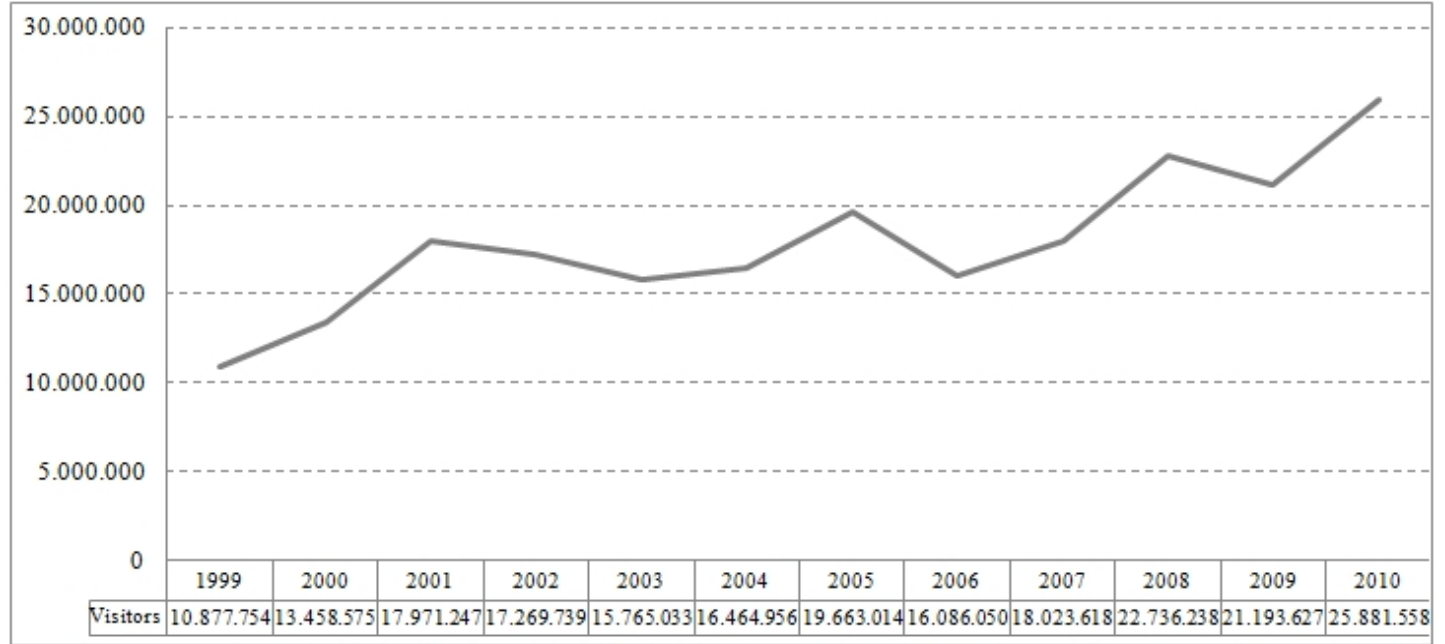

Figure 5. Visitors of Museums in Turkey According to Years

Adapted from the Data of TÜIK, the Data of General Directorate of Cultural Heritage and Museum and the Data of Ministry of Culture and Tourism 


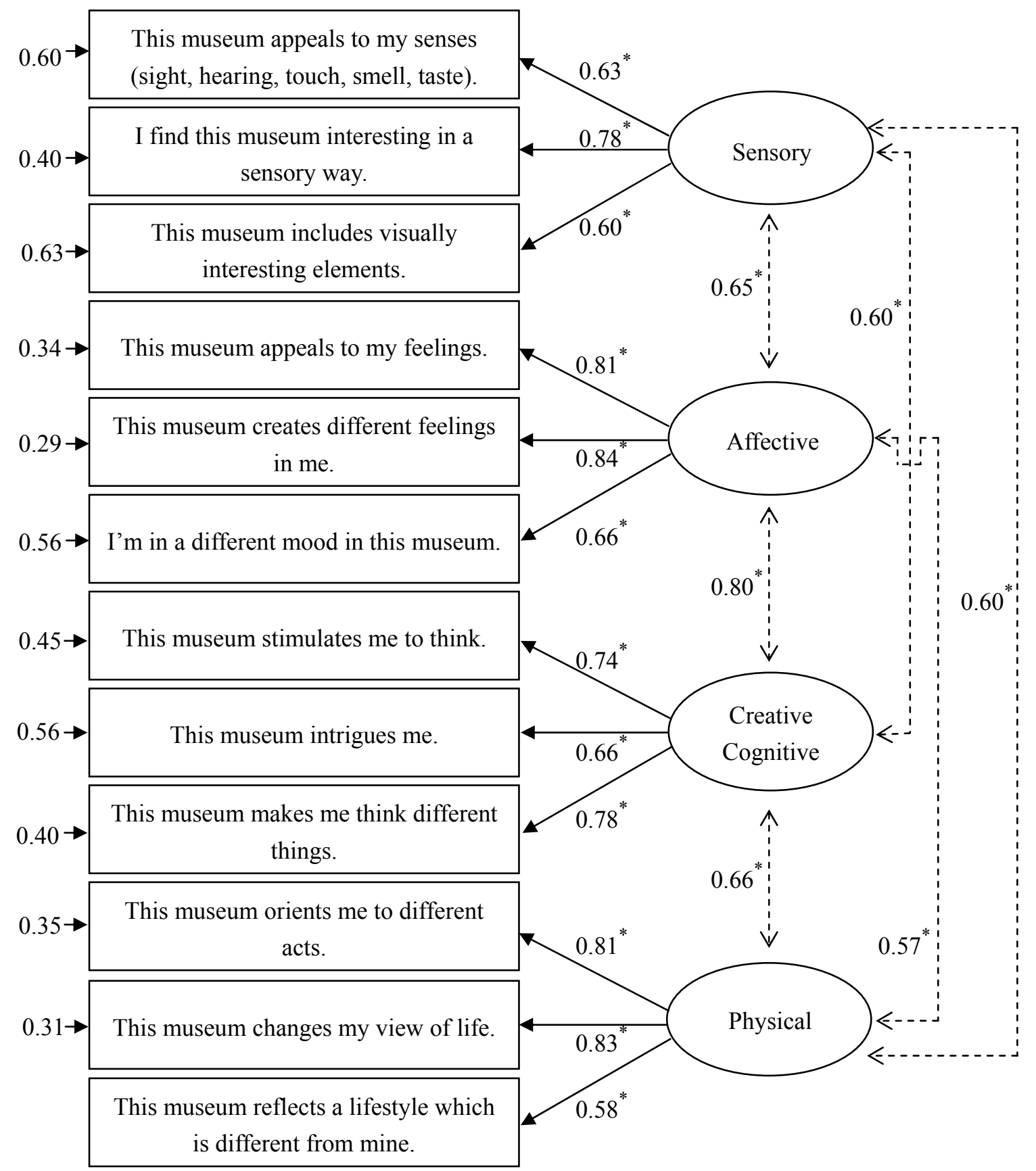

Figure 6. Confirmatory Factor Analysis for Customer Experiences

Notes: ${ }^{*} p<0.05$. All coefficient values are standardized and appear near the associated path. Dotted lines represent correlations. 


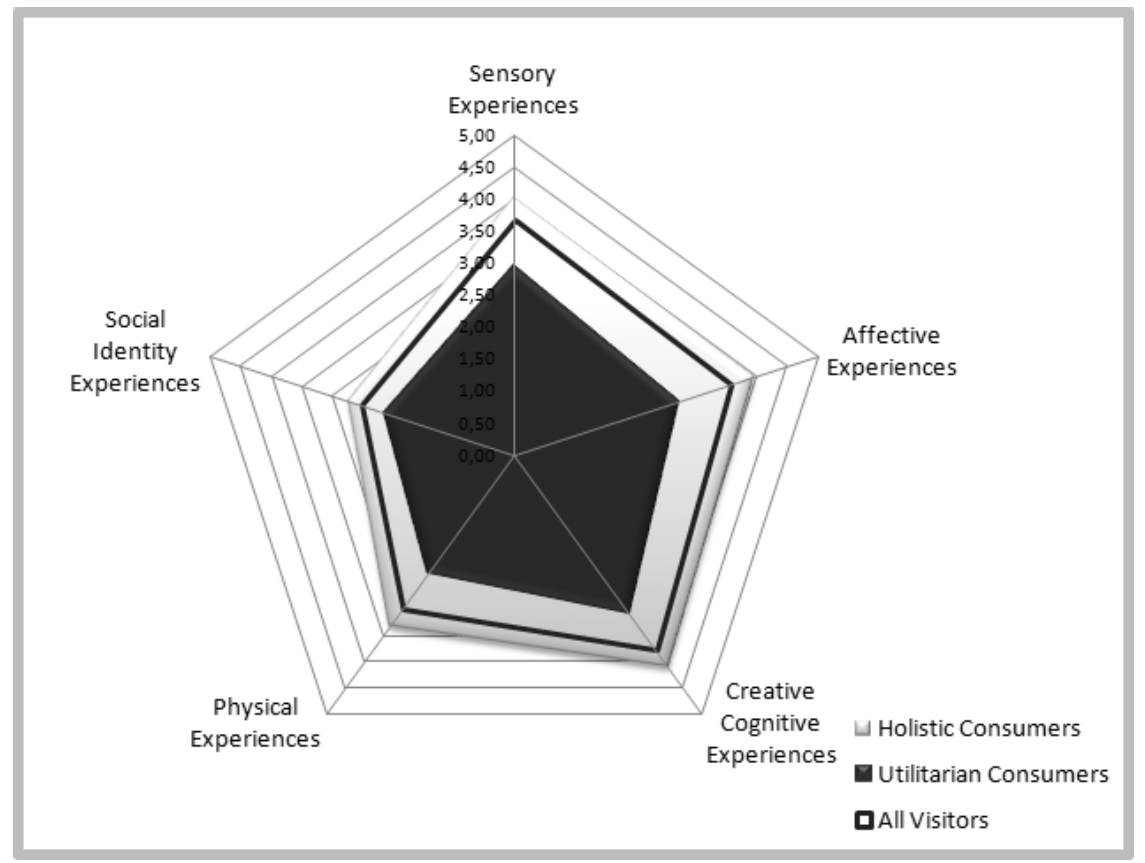

Figure 7. Radar Chart of Clusters Based on Customer Experiences

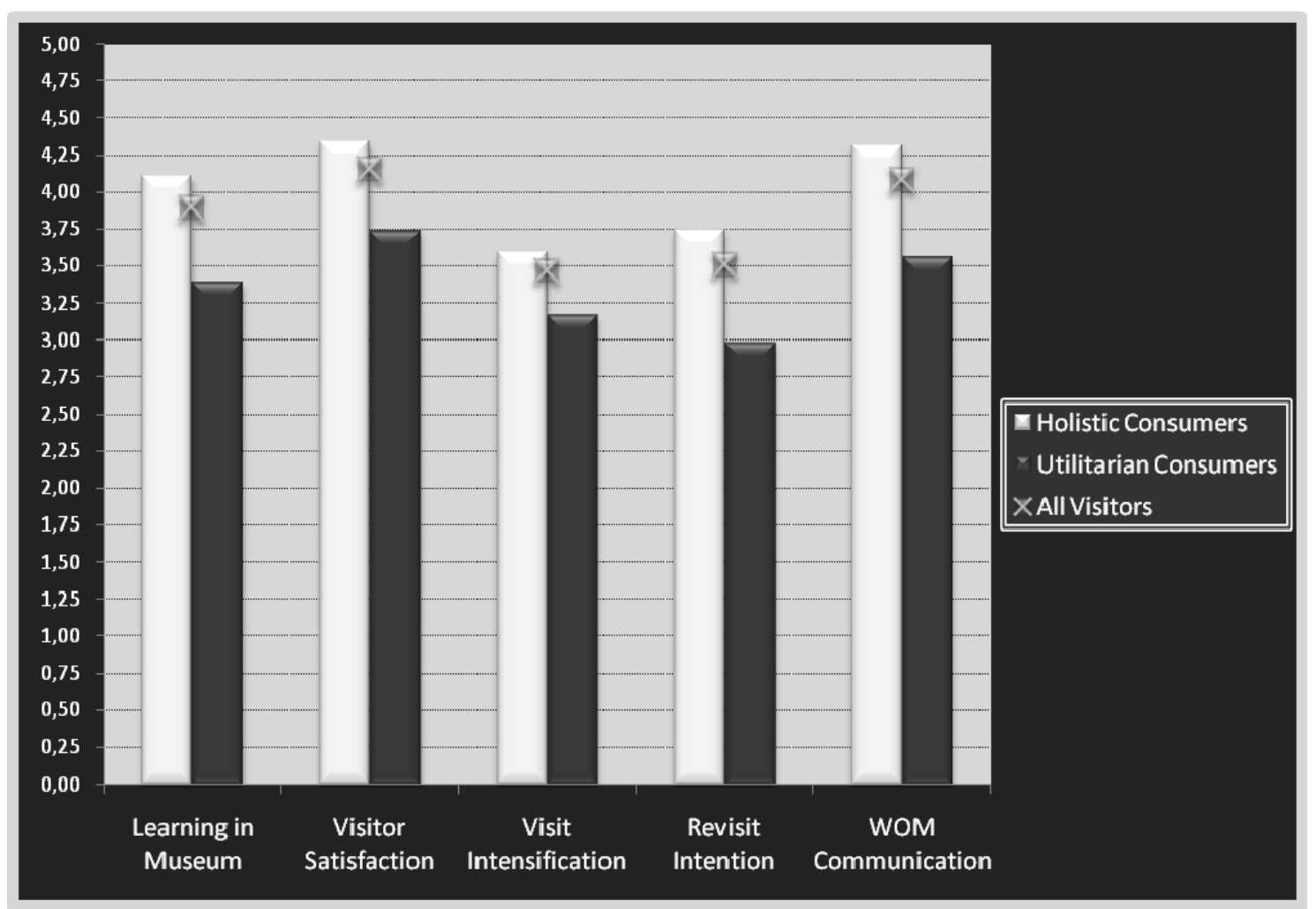

Figure 8. The Differences for Post Experience Dimensions between Clusters Based on Customer Experiences 